\author{
Angelina DEMCHUK, \\ orcid.org/0000-0003-0894-1684 \\ Candidate of Philological Sciences, \\ Associate Professor at the Department of Germanic Philology and Methodology \\ of Teaching Foreign Languages \\ South Ukrainian National Pedagogical University named after K. D. Ushynsky \\ (Odesa,Ukraine) angelinushka12@yahoo.com
}

\title{
GENDER PECULIARITIES OF VOICE PERCEPTION AND ITS VERBALIZATION IN THE ENGLISH DETECTIVE PROSE
}

The study is devoted to the gender differences in voice perception and their reflection in the English detective prose. The purpose of the research is to analyze voice gender markers and the means of their verbalization in female and male detective discourse. Basing on our previous research and preliminary obtained results, the leading prosodic characteristics and their combinations were singled out in the female (J. Mc Gown, D. Crombie) and male (B. Black, L. Child) authors. The quantitative analysis of the word usage frequency allows highlighting the salient differences in female and male voice perception: loudness and voice quality are the most significant in the process of voice perception in males; the combinations of the prosodic characteristics and loudness - in females. Playing a leading role for both genders, loudness is proved to be perceived differently as female and male authors demonstrate an opposite-gender bias.

The comparative analysis of the female and male vocabulary was carried out. It shows how females and males discriminate the same prosodic characteristic: a verbalized precise voice quality goes first in the reflection of voice quality perception in the male detective discourse, a shaking voice quality - in the female writers; the voice pitch range is more clearly perceived by males, and the tone movement direction - by females; the female authors predominantly verbalize the combination of loudness and voice quality; the combination of melody and loudness is salient for the male writers.

Along with gender differences in female and male voice perception, the general features were identified: it is easier to perceive and therefore to nominate two of the prosodic characteristics than three or four, irrespectively of the gender; tempo plays an insignificant role in voice perception for males and females. Male voices are perceived as slow and female voices - as quick by both groups of authors. Overall, female and male authors verbalize voice gender markers that reflect vocal gender stereotypes generally accepted in the English-speaking community.

Key words: gender differences, voice perception, prosodic characteristic, detective discourse, verbalization.

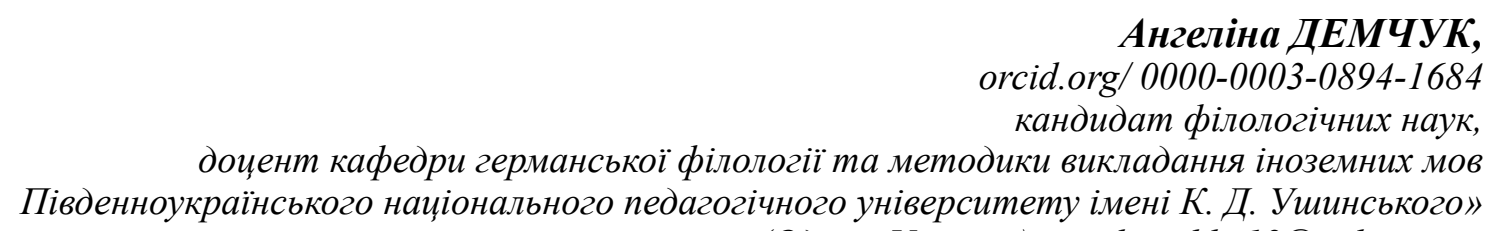

(Одеса, Україна) angelinushka12@yahoo.com

\section{ГЕНДЕРНІ ОСОБЛИВОСТІ ПЕРЦЕПЦІї ГОЛОСУ ТА ІІЇ ВЕРБАЛІЗАЦІї В АНГЛОМОВНІЙ ДЕТЕКТИВНІЙ ПРОЗІ}

Устатті досліджено гендерні розбіжності голосової периепиіїта ї̈ віддзеркалення в англомовній детективній прозі. Метою дослідження є аналіз голосових гендерних маркерів та засобів їх вербалізації у фемінному та маскулінному детективному дискурсі. Базуючись на результатах проведених нами досліджень, ми виокремили найбільш значущі просодичні характеристики та їх комбінаџї у авторів-жінок (Дж. МакГроу, Д. Кромбі) та авторів-чоловіків (Б. Блек, Л. Чайлд). Кількісний аналіз частотності слововживань дав змогу дійти висновку про те, шо гучність та якість голосу є салієнтними параметрами у сприйнятті голосу для чоловіків, а комбінації просодичних характеристик і гучність - для жінок. Незважаючи на те, щяо гучність відіграє ведучу роль як у маскулінному, так і у фемінному детективному дискурсі, доведено, щэо иеей просодичний параметр сприймається жінками та чоловіками по-різному.

Здійснено компаративний аналіз «жіночого» та «чоловічого» вокабуляру. Результати аналізу демонструють гендерні розбіжності у периепиії окремих просодичних характеристик: вербалізована чітка якість голосу виявилася ведучою в маскулінному дискурсі, а тремтяча якість голосу - у фемінному; висота тону більш чітко сприймається чоловіками, а напрямок руху голосового тону - жінками; автори-жінки переважно вербалізують комбінації гучності та якості голосу; комбінації мелодики та гучності виявилися салієнтними для авторівчоловіків. 
Demchuk A. Gender peculiarities of voice perception and its verbalization in the English...

Разом із тендерними розбіжностямижіночоїта чоловічоїголосовоїперцепиіїбуло також виокремлено загальні риси: два просодичні параметри сприймаються чіткіше й, як наслідок, вербалізуються авторами частіше, ніж три або чотири параметри незалежно від гендера; темп виявився найменш значущою характеристикою голосової периепиії як для жінок, так і для чоловіків. Чоловічі голоси сприймаються переважно як повільні, а жіночі - як ивидкі обома групами письменників. Загалом вербалізовані голосові тендерні маркери відображають фемінні та маскулінні голосові стереотипи, загальноприйняті в англомовному колективі.

Ключові слова: тендерні розбіжності, голосова перцепція, просодична характеристика, детективний дискурс, вербалізація.

Problem statement. The present article continues the research into gender aspects of voice perception and its verbalization in the English belles-lettres discourse. Gender peculiarities in voice perception are being actively studied by modern psychologists and behavioral scientists. However, the reflection of gender aspects in voice perception in the English language has not been profoundly researched yet.

My preliminary results of the comparative analysis state that in female belles-lettres discourse the most important markers in voice perception are verbalized prosodic characteristics of voice quality (firstly, tense voice quality) and combinations of two and three parameters, predominantly combinations of high pitch and increased loudness, slurred voice quality and decreased loudness. Domination of combinations proves female voice perception to be more accurate that is reflected in more detailed description of the voice prosodic characteristics. Unlike female author in the male belles-lettres discourse voice perception is verbalized in a more general way, foregrounding only one prosodic parameter - loudness. A common feature of female and male voice perception is that melody and tempo appear to be the least significant prosodic characteristics (Demchuk, 2020).

To provide more profound and verified data of the research into gender peculiarities in voice perception and its verbalization in the English language it is necessary to enlarge the corpus of English belles-lettres texts of different genres.

Analysis research. The results of the previous studies in voice perception highlight the integral relationship between cognitive and perceptual mechanisms of this process (Nagels, et al., 2020) and claim that men and women perceive human voices differently. Having analyzed P. Belin's model of voice perception (Belin et al., 2004) it becomes clear that vocal speech and affect analyses as well as voice recognition process take place in different cortical regions in males and females. The perception of male and female voices activates distinct brain regions in the male brain (Sokhi et al., 2005).

Thus, gender is considered to be an important factor that influences the accuracy in decoding vocal emotions (Bonebright et al., 1996; Thomson, Voyer, 2014; Lambrecht et al., 2014). Various studies prove that female and male perceive vocal emotions differently, and females are more precise in their recognition (Lausen, Schacht, 2018; Memon, Dhamyal, 2019). Women demonstrate ability to precise identification of male as well as female voices meanwhile men are inclined to more accurately identify male voices (Skuk, Schweinberger, 2012). Such conclusions sustain my preliminary findings (Demchuk, 2020).

The purpose of the article is to study how gender differences in voice perception are reflected in the English female and male detective discourse. The object of the present research is voice perception verbalization, and the subject is gender differences of voice perception verbalization in female and male detective prose.

Presentation main material. This time the material of the study is English detective prose written by two female and two male authors: Jill Mc Gown "A shred of evidence", Deborah Crombie "Garden of lamentations"; Lee Child "Killing floor", Benjamin Black "A death in summer". The semantic analysis of the lexical units that verbalize voice perception in the terms of voice prosodic characteristics (melody, loudness, tempo, voice quality and their combinations) in the female and male detective prose is based on the results of my previous research (Demchuk, 2009).

The quantitative analysis proves that the female authors' vocabulary is richer but not significantly. It comprises 88 constituents meanwhile the male authors' vocabulary is only 15 lexical units less (total 73). The results of distributive analysis of the vocabulary units totally in male and female authors are shown in table 1 .

As we can observe, the vocabulary of verbalized voice quality is diverse enough in both female and male detective writers and is $17.5 \%$ of the total quantity against $15.2 \%$. The percentage of the lexical units nominating combinations of prosodic characteristics is practically even in the female and male discourses $-8.0 \% / 7.3 \%$ correspondingly. The difference is registered in the percentage of the verbalized loudness, melody and tempo. Female vocabulary of these three prosodic characteristics is richer than male one: $15.3 \% / 11.0 \% ; 10.0 \% / 7.3 \% ; 5.0 \% / 3.0 \%$.

The comparative analysis of the female and male vocabulary shows that the leading prosodic charac- 
Distribution of the vocabulary units

\begin{tabular}{|c|c|c|c|c|c|c|}
\hline $\begin{array}{c}\text { Prosodic } \\
\text { characteristics }\end{array}$ & Loudness & Melody & $\begin{array}{l}\text { Voice } \\
\text { quality }\end{array}$ & Tempo & $\begin{array}{c}\text { Combinations } \\
\text { of characteristics }\end{array}$ & Total \\
\hline Female authors & $15.3 \%$ & $10.0 \%$ & $17.5 \%$ & $5.0 \%$ & $8.4 \%$ & \multirow{2}{*}{$100 \%$} \\
\hline Male authors & $11.0 \%$ & $7.3 \%$ & $15.2 \%$ & $3.0 \%$ & $7.3 \%$ & \\
\hline
\end{tabular}

Table 2

Comparative distribution of the vocabulary units in the female and male detective discourses

\begin{tabular}{|l|c|c|c|c|c|c|}
\hline $\begin{array}{c}\text { Prosodic } \\
\text { characteristics }\end{array}$ & Loudness & Melody & $\begin{array}{c}\text { Voice } \\
\text { quality }\end{array}$ & Tempo & $\begin{array}{c}\text { Combinations } \\
\text { of characteristics }\end{array}$ & Total \\
\hline Female authors & $33.0 \%$ & $17.0 \%$ & $25.0 \%$ & $14.5 \%$ & $10.5 \%$ & $100 \%$ \\
\hline Male authors & $24.8 \%$ & $15.2 \%$ & $37.5 \%$ & $6.9 \%$ & $16.6 \%$ & $100 \%$ \\
\hline
\end{tabular}

teristic in voice perception is voice quality for the male authors $(37.5 \%)$ and loudness $(33.0 \%)$ - for the female ones. The less "perceptible" appears the prosodic characteristic of tempo $(6.9 \%)$ for the males and combinations of prosodic parameters $(10.5 \%)-$ for the females. The results of the comparative analysis are given in table 2 .

It is interesting to note that prosodic characteristic of loudness is predominantly rendered by the lexical units nominating decreased loudness in female and male authors. Thus, in the female detective prose the following 17 lexical units were singled out: to hiss, whisper, to whisper, level, levelly, little, gentle, gently, weak, weakly, calm, calmly, small, soft, softly, quiet, quietly. The male vocabulary of decreased loudness consists of 10 lexical units: to hiss, whisper, to whisper, gentle, gently, quietly, calm, softly, weakly, small. The increased loudness is mainly verbalized by the phonation verbs to shout, to cry, to explode, to exclaim, to whoop, to burst out and by the adjective loud, adverb loudly in male as well as female authors. Prevalence of the decreased loudness vocabulary is explained by the peculiarities of the detective genre to emotionally involve the reader through mystery, suspense, thrill or fear, creating a tense atmosphere of the crime investigation.

The male authors' vocabulary of voice quality comprises lexical units that verbalize such voice qualities as: 1) hoarse (hoarse), 2) trembling (to quiver), 3) tense (tense, tight), 4) casual (to slur, casually), 5) precise (distinct, precise, clear), 6) resonant (resonant), 7) nasal (twang), 8) deep (deep, full), 9) breathy (breathily); metaphoric lexical units nominating 10) cold (cold, icy, icily), 11) sweet (sweet, sweetness), 12) dark (darkly, dully), 13) light (lightly) voice qualities. As for the female authors the following lexical units form the voice quality vocabulary: 1) hoarse; 2) to shake, to tremble, to waver, wobbling, tremor; 3) eagerly; 4) casual, casually; 5) precise, distinct, clearly; 6) full; 7) muffled; metaphoric lexical units: 8) cool, coolly, coldly; 9) warm; 10) sweet, sweetly; 11) darkly, dully, gloomily; 12) brightly; 13) light; 14) heavy; 15) steel.

Thus, the main differences in voice quality perception in males and females are as follows: the male authors first of all perceive precise voice quality meanwhile the female authors foreground trembling voice quality. Metaphoric lexical units are more diverse in the female detective discourse that demonstrate females' inclination to artistic and aesthetically exquisite world perception in general and voice perception in particular.

As for the melody vocabulary in the female detective discourse the pitch and the speed of pitch change are appeared to be leading melody components verbalized by adjectives (high, sharp, hard, low-pitched) and adverbs (sharply, crisply, briskly, mildly). The same tendency is observed in the male discourse. However, the lexical units nominating pitch range (flat, evenly) were singled out exceptionally in the male discourse. The verbalized tone movement direction (sing-song) occurred only in female authors. It is noteworthy that this prosodic characteristic is nominated both directly (sing-song voice) and indirectly (his voice very Welsh; he sounded very Welsh) (about specific sing-song melody of the Welsh voices see (Shevchenko, 1986)).

Tempo is verbalized by rather restricted quantity of lexical units both in male and female detective discourse. The quickened tempo is nominated by adverbs promptly, quickly, hurriedly; adjective fast; and noun rush in the male authors. Meanwhile the female writers, along with adverbs hurriedly and quickly, prefer verbs to sputter, to spit out, to blurt out. To nominate slow tempo both female and male authors employ the same lexical units: slowly, drawl, slow drawl. The comparative analysis of tempo vocabulary shows that female detective writers' vocabulary is more diverse in comparison with male ones. 
Demchuk A. Gender peculiarities of voice perception and its verbalization in the English...

Combinations of prosodic characteristics are presented by the following lexical units in the female detective discourse: to murmur, murmur, to yell (melody + loudness); to mutter, to mumble, to falter (loudness + voice quality); to snap (melody + tempo); to croak, metallic (melody + voice quality); to wail (melody + loudness + tempo); to bark, sheepish (melody + loudness + voice quality). In the male detective discourse such verbs as to scream, scream, to yell, to shriek, to murmur (melody + loudness); to snap (melody + tempo); to mutter, to mumble (loudness + voice quality); to growl (melody + tempo + voice quality); to squeak (melody + loudness + tempo), to rumble, rumble (loudness + melody + voice quality + tempo).

In the female detective discourse the combination of loudness and voice quality has a wider variety in comparison with other combinations, to be more precise, the combination of decreased loudness and indistinct voice quality (mutter, mumble) as well as decreased loudness and trembling voice quality (falter). These data sustain a leading role of the prosodic characteristics of loudness and voice quality in the process of voice perception by females. The male authors firstly perceive and therefore verbalize the combination of melody and loudness: high pitch and increased loudness (scream, shriek, yell) as well as low pitch and decreased loudness (murmur). It seems to go against the obtained data that prove a verbalized voice quality to be the salient prosodic parameter. However, the explanation can be found in the process of the further analysis aimed at discriminating typical female and male prosodic characteristics in the detective discourse. In this connection, we state that verbalized combinations of high pitch and increased loudness are mainly used to describe female voices in the male detective discourse: "the woman said, almost a scream" (Black, 2011); "I'll tear your head off", Roscoe yelled" (Child, 2012); "More cops?" she screamed. "Shit!" (Child, 2012).

The vocabulary of verbalized combinations of prosodic characteristics demonstrates a strong tendency to nominate predominantly two parameters rather than three or four. It reflects the voice perception process: independent of a gender a person can easily perceive one or two vocal cues. The gender peculiarities of voice perception are manifested in foregrounding definite prosodic characteristics and their combinations.

To find out which prosodic characteristic is the most significant in voice perception for male and female authors the analysis of word usage frequency was carried out. The word corpus consists of 226 lexical units in the female discourse and 143 lexical units in the male discourse. The results of the analysis are presented in table 3.

The frequency occurrence analysis shows somewhat different results in comparison with the vocabulary analysis. In the female discourse the lexical units nominating combinations of prosodic characteristics $(20.7 \%)$ are used more frequently than the voice quality verbalizers $(16.8 \%)$. Though the nominators of loudness still prevail. The male authors incline to verbalize loudness (39.3\%) more frequently than voice quality $(22.3 \%)$ and combinations of prosodic characteristics (19.5\%). The prosodic parameter of tempo is proved to be the least significant for both female and male authors $(12.0 \% / 3.5 \%)$.

Analyzing the word usage frequency in the female and male detective discourse the overall gender differences in female and male voice perception were distinguished. They are clearly shown in how female authors as well as male ones perceive male and female voices. The female authors predominantly describe male voices as loud, low-pitched, slow, hoarse, dull, distinct, and heavy. Meanwhile female voices are quiet, high-pitched, quick, shaking, light, and warm. The male authors mainly discriminate the following voice characteristics in the males: quiet, sharp, flat, slow, resonant, deep, and precise. The lexical units nominating pitch range were used to describe male voices only. The female voices are loud, high-pitched/ mild, quick, slurred, tense, breathy, and sweet.

Thus, the female authors ascribe to the male voices such prosodic characteristics as increased loudness, low pitch, sharp falling tone, slow tempo, and hoarse, precise, dull, heavy voice qualities. For the male authors the general prosodic characteristics of men's voices are decreased loudness, sharp falling tone, monotone, slow tempo, and resonant, deep, precise voice qualities.

As we can observe, the main peculiarities in male voice perception by females and males are reflected in the prosodic characteristics of loudness (increased/

Table 3

Word usage frequency in female and male detective discourses

\begin{tabular}{|l|c|c|c|c|c|c|}
\hline $\begin{array}{c}\text { Prosodic } \\
\text { characteristics }\end{array}$ & Loudness & Melody & $\begin{array}{c}\text { Voice } \\
\text { quality }\end{array}$ & Tempo & $\begin{array}{c}\text { Combinations } \\
\text { of characteristics }\end{array}$ & Total \\
\hline Female authors & $26.4 \%$ & $11.5 \%$ & $16.8 \%$ & $12.0 \%$ & $20.7 \%$ & $100 \%$ \\
\hline Male authors & $39.3 \%$ & $15.4 \%$ & $22.3 \%$ & $3.5 \%$ & $19.5 \%$ & $100 \%$ \\
\hline
\end{tabular}


decreased); melody (low pitch/sharp falling tone, monotone); voice quality (hoarse, dull, heavy/resonant, deep). The general feature of male voice perception is slow tempo.

As for the female voice perception, the male authors foreground such prosodic parameters as increased loudness, high pitch and low pitch, quick tempo, and indistinct, tense, breathy, sweet voice qualities. In their turn, female writers characterize women's voices by decreased loudness, high pitch, quick tempo, and shaking, light, warm voice qualities. In female voice perception there is one general feature - quick tempo. The main gender differences manifest themselves in the prosodic characteristics of melody (high pitch / high pitch and low pitch) and voice quality (indistinct, tense, breathy, sweet / shaking, light, warm).

These findings actually reflect existing stereotypes about the voice gender perception: female voices are characterized as high-pitched (one octave higher than male voices) and breathy (Latinus \& Taylor, 2011; Klatt \& Klatt, 1990); male voices are perceived as deep because they have thicker vocal cords (Watson, 2019). However, the fundamental frequency falls in women and rises in men after the middle age (Zaske et al., 2013). This fact explains why female voices are described either as low-pitched by the male authors; speakers' age obviously influences the voice gender perception as well as its verbalization.

Conclusions. The present research results prove females and males perceive voices differently that is reflected in its verbalization means in the female and male detective discourse. The salient differences between female and male voice perception manifested themselves in the indexes of word usage frequency according to which the most significant prosodic characteristics in voice perception for women are loudness and combinations of prosodic parameters meanwhile for men they are loudness and voice quality. In spite of loudness playing a leading role both in female and male detective discourses it is perceived differently. Female and male authors dem- onstrate an opposite-gender bias, i.e. females identify male voices as loud and vice versa and voices of their own gender as quiet. This fact allows to presume that the opposite gender voices seem to sound with higher degree of intensity. The general prevalence of verbalized decreased loudness is explained by the specificity of the detective genre.

The comparative analysis of female and male vocabulary shows a clear discrimination between female and male perception of the same voice prosodic characteristic: a precise voice quality appears to be the most significant for the male authors, meanwhile the female writers foregrounds a shaking voice quality; the voice pitch range is more clearly perceived by males, and the tone movement direction - by females. As for the combinations of prosodic parameters, the female authors firstly perceive and verbalize the combination of loudness and voice quality; the combination of loudness and melody proves to be salient for the males.

Besides gender differences in female and male voice perception, the general features were identified. There is a strong tendency to perceive and nominate two of the prosodic characteristics irrespectively of the gender. Tempo is the least significant in voice perception for both males and females. However, slow tempo is typical of male voices and quick tempo is common for the female voices in female and male voice perception. In general, verbalized voice gender markers predominantly reflect vocal female and male stereotypes generally accepted in the English-speaking community.

In conclusion, the results of the present study do not completely sustain the findings of our preliminary research. Thus, it is suggested that genre of the belleslettres text may influence the verbalization of voice gender markers in the male and female discourse.

The perspective of this research is to study gender differences in voice perception and its verbalization on the basis of the English dramatic discourse and to compare results with previously collected data.

\section{BIBLIOGRAPHY}

1. Демчук А. И. Вербализация просодических характеристик голоса в современном английском языке (на материале словарей и художественных текстов) : дисс. ... канд. филол. наук : спец. 10.02.04. Одесса. 2010.251 с.

2. Шевченко Т. И. Социальная вариативность английской интонации : учебное пособие. Москва, 1986. 123 с.

3. Belin P., Fecteua Sh., Bedard C. Thinking the voice: neural correlates of voice perception. Trends in cognitive science. 2004. № 8 (3). P. 129-135. DOI: https://doi.org/10.1016/j.tics.2004.01.008.

4. Black B. A Death in Summer. URL: https://graycity.net/benjamin-black/page,3,104718-a_death_in_summer.html.

5. Bonebright T. L., Thompson J. L. \& Leger D. W. Gender stereotypes in the expression and perception of vocal affect. Sex Roles. 1986. № 34. P. 429-445. DOI: https://doi.org/10.1007/BF01547811.

6. Child L. Killing Floor. URL: https://graycity.net/lee-child/page,17,2000-killing floor.html.

7. Crombie D. Garden of Lamentations. URL: archive.bookfrom.net/deborah-crombie/174458-the_garden_of_ lamentations.html.

8. Demchuk A. Gender aspects of voice perception verbalization in the English belles-lettres discourse: preliminary research. South archive (philological sciences). 2020. 83. DOI: https://doi.org/10.32999/ksu2663-2691/2020-83-7. 
9. Lambrecht L., Kreifelts B., Wildgruber D. Gender differences in emotion recognition: Impact of sensory modality and emotional category. Cognition and emotion. 2014. № 28 (3). P. 452-469. DOI: 10.1080/02699931.2013.837378.

10. Latinus M., Taylor M. J. Discriminating male and female voices: differentiating pitch and gender. Brain Topography. 2011. № 25 (2). P. 194-204. DOI: 10.1007/s10548-011-0207-9.

11. Lausen A. Schacht A. Gender differences in the recognition of vocal emotions. Frontiers in psychology. 2018. № 9. DOI: https://doi.org/10.3389/fpsyg.2018.00882.

12. MacGown J. The Shred of Evidence. URL: https://archive.bookfrom.net/jill-mcgown/page,32,268016-a_shred_of_ evidence.html.

13. Memon S. A., Dhamyal H. Detecting gender differences in perception of emotion in crowdsourced data. URL: https://arxiv.org/pdf/1910.11386.pdf. 2019. DOI: 10.1145/1235.

14. Nagels, L., Gaudrain, E., Vickers, D. et al. Development of voice perception is dissociated across gender cues in school-age children. 2020. Sci Rep 10, 50-74. URL: https://www.nature.com/articles/s41598-020-61732-6\#citeas.

15. Skuk V., Schweinberger S. Gender Differences in Familiar Voice Identification. Hearing research. 2012. URL: https://www.researchgate.net/publication/233737433_Gender_Differences_in_Familiar_Voice_Identification.

16. Sokhi D. S., Hunter M. D., Wilkinson I. D., Woodruff P. Male and female voices activate distinct regions in the male brain. Neuoro Image 27, 2005. P. 572-578. DOI: https://doi.org/10.1016/j.neuroimage.2005.04.023.

17. Thomson A. E., Voyer D. Sex differences in the ability to recognize non-verbal displays of emotion: a meta-analysis. Cognition and emotion. 2014. № 28 (7). P. 1164-1195. DOI: https://doi.org/10.1080/02699931.2013.875889.

18. Watson S. The unheard female voices. The ASHA leader. 2019. № 24 (2). DOI: https://doi.org/10.1044/leader. FTR1.24022019.44.

19. Zaske R., Skuk V., Kaufmann J. M., Schweinberger S. R. Perceiving vocal age and gender: An adaptation approach. Acta Psychologica. 2013. № 144 (3). P. 583-593. DOI: 10.1016/j.actpsy.2013.09.009.

\section{REFERENCES}

1. Demchuk A. I. (2010) Verbalizatsiya prosodicheskih kharakteristic golosa $v$ sovremennom angliyskom yazyke (na materiale slovarey I khudozhestvennyh tekstov). [Voice prosodic characteristics verbalization in the modern English language (on the basis of dictionaries and belles-lettres texts)]. Thesis for the degree of the Candidate of Sciences in Philology: 10.02.04. Odessa, 251 p. [in Russian].

2. Shevchenko T. I. Sotsialnaya variativnost angliyskoy intonatsii: [Social variety of the English intonation]. Moscow, 1986. 123 p. [in Russian].

3. Belin P., Fecteua Sh., Bedard C. Thinking the voice: neural correlates of voice perception. Trends in cognitive science. 2004. 8 (3). pp. 129-135. https://doi.org/10.1016/j.tics.2004.01.008.

4. Black B. A Death in Summer. URL: https://graycity.net/benjamin-black/page,3,104718-a_death_in_summer.html.

5. Bonebright, T. L., Thompson, J. L. \& Leger, D. W. Gender stereotypes in the expression and perception of vocal affect. Sex Roles. 1986. 34. pp. 429-445. https://doi.org/10.1007/BF01547811.

6. Child L. Killing Floor. URL: https://graycity.net/lee-child/page,17,2000-killing_floor.html.

7. Crombie D. Garden of Lamentations. URL: archive.bookfrom.net/deborah-crombie/174458-the_garden_of_lamentations.html.

8. Demchuk A. Gender aspects of voice perception verbalization in the English belles-lettres discourse: preliminary research. South archive (philological sciences). 2020. 83. DOI: https://doi.org/10.32999/ksu2663-2691/2020-83-7.

9. Lambrecht L., Kreifelts B., Wildgruber D. Gender differences in emotion recognition: Impact of sensory modality and emotional category. Cognition and emotion. 2014. 28 (3). pp. 452-469. doi: 10.1080/02699931.2013.837378.

10. Latinus M., Taylor M. J. Discriminating male and female voices: differentiating pitch and gender. Brain Topography. 2011. 25 (2). pp. 194-204. DOI: 10.1007/s10548-011-0207-9.

11. Lausen A. Schacht A. Gender differences in the recognition of vocal emotions. Frontiers in psychology. 2018. № 9. https://doi.org/10.3389/fpsyg.2018.00882.

12. MacGown J. The Shred of Evidence. URL: https://archive.bookfrom.net/jill-mcgown/page,32,268016-a_shred_of_ evidence.html.

13. Memon S. A., Dhamyal H. Detecting gender differences in perception of emotion in crowdsourced data. URL: https://arxiv.org/pdf/1910.11386.pdf. DOI: 10.1145/1235.

14. Nagels, L., Gaudrain, E., Vickers, D. et al. Development of voice perception is dissociated across gender cues in school-age children. 2020. Sci Rep 10, 50-74. URL: https://www.nature.com/articles/s41598-020-61732-6\#citeas.

15. Skuk V., Schweinberger S. Gender Differences in Familiar Voice Identification. Hearing research. 2012. URL: https://www.researchgate.net/publication/233737433_Gender_Differences_in_Familiar_Voice_Identification.

16. Sokhi D. S., Hunter M. D., Wilkinson I. D., Woodruff P. Male and female voices activate distinct regions in the male brain. Neuoro Image. 2005. № 27. pp. 572-578. https://doi.org/10.1016/j.neuroimage.2005.04.023.

17. Thomson A. E., Voyer D. Sex differences in the ability to recognize non-verbal displays of emotion: a meta-analysis. Cognition and emotion. 2014. 28 (7). pp. 1164-1195. https://doi.org/10.1080/02699931.2013.875889.

18. Watson S. The unheard female voices. The ASHA leader. 2019. 24 (2). https://doi.org/10.1044/leader.FTR1. 24022019.44 .

19. Zaske R., Skuk V., Kaufmann J. M., Schweinberger S. R. Perceiving vocal age and gender: An adaptation approach. Acta Psychologica. 2013. 144 (3). pp. 583-593. DOI: 10.1016/j.actpsy.2013.09.009. 